\title{
ANAESTHESIA FOR OPEN-HEART SURGERY IN HAEMODIALYSIS-DEPENDENT PATIENTS: A REPORT OF TWO CASES
}

\author{
Forrest B. Allen and Peter B. Kane
}

\begin{abstract}
Two cases are presented in which patients in chronic renal failure underwent successful open heart surgery. The additional problems chronic renal failure imposes on the anaesthetic management of patients requiring cardiac surgery are discussed, with recommendations on choice of agents and techniques.
\end{abstract}

KEY WORDS: SURGERY, cardiac; KIDNEY, chronic failure; ANAESTHETIC TECHNIQUES, general.

THE HAEMODIALYSIS-DEPENDENT patient requiring open-heart surgery presents an unusual challenge to the anaesthetist. Life sustaining haemodialysis does not correct all of the metabolic derangements associated with renal failure and some may, in fact, be exacerbated. ' Chronic haemodialysis appears to accelerate atherosclerotic vascular disease ${ }^{2}$ and the presence of an arterio-venous shunt or fistula may increase the incidence of bacterial endocarditis. ${ }^{3}$ Ultimately 50 to 65 per cent of patients with chronic rena failure die as a result of cardiovascular complications. ' While several groups have reported open-heart surgery in haemodialysis-dependen patients, ${ }^{4-9}$ only two consider the anaesthetic management. ${ }^{10,11}$ Of these, one deals with combined cardiac and renal transplantation ${ }^{10}$ the other with aortic valve replacement. "I This report presents the anaesthetic management of two haemodialysis-dependent patients requiring open-heart surgery.

\section{CAse Reports}

\section{Patient \#I}

A 55-year-old Caucasian male with a one year history of angina and intermittent atrial fibrillation was admitted for cardiac catheterization and angiography. Pertinent catheterization data included a left ventricular end-diastolic pressure of

Forrest B. Allen, M.D., Assistant Professor; Peter B. Kane, M.D., Associate Professor; Department of Anesthesiology, State University of New York, Upstate Medical Center, 750 East Adams Street, Syracuse, New York 13210, U.S.A.

Address correspondence to Peter B. Kane, M.D. 158
$20 \mathrm{mmHg}$ falling to $15 \mathrm{mmHg}$ following injection of contrast media. The ejection fraction was 75 per cent following sublingual nitroglycerin. Triple vessel coronary artery disease was demonstrated and the patient was discharged pending coronary artery bypass grafting. Three weeks after catheterization the patient became anuric, an unusual but recognized late complication of angiography. ${ }^{12}$ An arterio-venous fistula was created for haemodialysis and the patient was scheduled for the coronary artery bypass graft procedure one month after being stabilized Concomitant medication included methyldopa, quinidine, digoxin, isosorbide dinitrate and nitroglycerin. Physical examination revealed a healthy-looking muscular male weighing $80 \mathrm{~kg}$. Blood pressure ranged from $14.6 / 8$ to $21.3 / 12$ $\mathrm{kPa}(110 / 60$ to $160 / 90 \mathrm{mmHg})$ while the pulse rate varied between 52 and 86 per minute. The haematocrit was 30.

Haemodialysis was done the day before operation. Serum potassium at 7 a.m. on the day of the operation was $5.1 \mathrm{mmol} / \mathrm{l}$. Premedication consisted of morphine $10 \mathrm{mg}$ and scopolamine $0.4 \mathrm{mg}$ administered intramuscularly one hour before induction of anaesthesia.

Percutaneous arterial and central venous pressure (CVP) catheters were inserted and connected to an appropriate monitor. Oxygen was administered by mask while anaesthesia was induced with incremental doses of Innovar $(6 \mathrm{ml}$.$) and diazepam (20 \mathrm{mg})$. Following tubocurarine $3 \mathrm{mg}$, succinylcholine $100 \mathrm{mg}$ was given to facilitate tracheal intubation. Controlled ventilation was instituted with nitrous oxide and oxygen (3:3 litres). Although it was necessary to 
infuse $250 \mathrm{ml}$ of plasma protein fraction to maintain a stable CVP, heart rate and arterial pressure were unchanged. Fentanyl was given incrementally during the procedure (total dose $0.8 \mathrm{mg}$ ). Halothane was administered intermittently to control hypertension resulting from surgical manipulation. The pump-oxygenator was primed with whole blood. Cardiopulmonary bypass lasted 121 minutes and was discontinued following placement of a catheter in the left atrium for pressure monitoring. Blood from the oxygenator reservoir was given to maintain left atrial pressure at 10 to $12 \mathrm{mmHg}$. Two units of fresh frozen plasma were administered; no additional transfusion was necessary in the operating room. Two units of packed cells were infused in the intensive care unit later, however, to replace mediastinal drainage.

Serum sodium and potassium levels were measured every thirty minutes, during and after bypass. The former ranged from 133 to 139 $\mathrm{mmol} / \mathrm{l}$, the latter from 5.0 to $5.3 \mathrm{mmol} / 1$.

Postoperatively the patient, awake and responsive, was taken to the intensive care unit where he was ventilated mechanically overnight. The following morning he was extubated.

Haemodialysis was done the day after operation and on alternate days until the patient was discharged from the hospital on the tenth postoperative day. Fifteen months after operation he is well and is being haemodialyzed at home three times a week.

\section{Patient \#2}

A 44-year-old Caucasian female with a fouryear history of renal failure requiring dialysis developed mitral insufficiency following bacterial endocarditis. She suffered two recent episodes of congestive heart failure and was admitted for mitral valve replacement.

Current medications included digoxin and vitamins. Physical examination revealed a pale, moderately obese woman weighing $70 \mathrm{~kg}$. Blood pressure ranged between $9.3 / 6.6$ to $12 / 8$ $\mathrm{kPa}$ (70/50 to $90 / 60 \mathrm{mmHg}$ ) while the heart rate varied between 76 and 100 . Haematocrit was 29 . The pulmonary artery pressure was $10 / 6 \mathrm{kPa}$ $(75 / 45 \mathrm{mmHg}$ ) with a pulmonary capillary wedge pressure of $4.4 \mathrm{kPa}(33 \mathrm{mmHg})$. Cardiac index was $2.41 \cdot \mathrm{min}^{-1} / \mathrm{m}^{2}$ at rest.

Haemodialysis was done the day before operation. Serum potassium was $3.8 \mathrm{mmol} / \mathrm{l}$ on the morning of the operation. Premedication consisted of hydroxyzine $50 \mathrm{mg}$ and morphine
$8 \mathrm{mg}$ intramuscularly one hour before induction of anaesthesia.

Percutaneous arterial and CVP catheters were placed and the pressures transduced to an appropriate monitor. After preoxygenation, anaesthesia was induced by incremental injections of diazepam (15 mg) and maintained with nitrous oxide, oxygen (3:3 litres) and halothane. Following pretreatment with pancuronium $1 \mathrm{mg}$ succinylcholine was administered to facilitate tracheal intubation. Ventilation was mechanically controlled following administration of pancuronium $5 \mathrm{mg}$. Blood pressure and heart rate remained within the patient's normal range as did the CVP. The anaesthetic course was uneventful. An additional $3 \mathrm{mg}$ of pancuronium was required toward the end of the 101 minute cardiopulmonary bypass. After mitral valve replacement, a left atrial pressure monitoring catheter was inserted and bypass was discontinued. Blood was transfused from the oxygenator reservoir to maintain left atrial pressure at $10 \mathrm{mmHg}$. Following decannulation of the heart two units of fresh-frozen plasma and one unit of whole blood were given to maintain arterial and left atrial pressures.

Serum sodium ranged from 132 to $136 \mathrm{mmol} / 1$ during the procedure. Serum potassium fell to $2.9 \mathrm{mmol} / \mathrm{l}$ during bypass. The addition of 22 mmol of potassium maintained a serum level of 3.7 to $4.2 \mathrm{mmol} / 1$.

Postoperatively, the patient was transferred to the intensive care unit awake and alert but with some residual neuromuscular blockade. Reversal was not attempted and following overnight mechanical ventilation and demonstration of satisfactory ventilatory reserve she was extubated.

Haemodialysis was done on the first postoperative day and on alternate days thereafter until discharge two weeks later. She did well for six months, at which time she fell down while alone at home, suffering a fatal subdural haematoma.

\section{Discussion}

The coexistence of chronic renal failure and cardiac disease produce unusual problems for the anaesthetist.

Preoperative assessment of the cardiovascular status is important, since dialysis-dependent patients are commonly hypertensive, further threatening what may be a very delicate haemodynamic balance. Hypervolaemia, a frequent 
cause of this elevated blood pressure, may be controlled by dialysis and fluid restriction. ${ }^{16,21} \mathrm{In}$ five per cent of patients with chronic renal failure the hypertension is characterized by its severity, high renin levels, and transient response to dialysis. ${ }^{16,21}$ While these patients require antihypertensive therapy, all hypertensive patients with chronic renal failure should be controlled before elective surgery.

The patient with chronic renal failure is usually anaemic, secondary to decreased erythropoietin formation and a shortened red cell life span. ${ }^{13}$ Opinions vary with regard to the minimum haematocrit permissible for elective surgery. ${ }^{4,7,14-16}$ The severity of the cardiac disease determines the degree of anaemia tolerated; patients with a limited or fixed cardiac output are less able to compensate. A careful history and record review should reveal what haematocrit is best tolerated by a particular patient. Since increase in red cell 2,3-diphosphoglycerate, in chronic renal failure is not commensurate with the anaemia, ${ }^{23}$ preoperative transfusion to a haematocrit of 30 or higher is desirable to provide reserve oxygen carrying capacity. Since multiple blood transfusions appear to favour subsequent renal allograft success and there is no advantage in the use of frozen red cells or leucocyte poor blood, whole blood or packed cells are administered as indicated. ${ }^{17-20}$ If preoperative transfusion is required, it is best done during haemodialysis when the circulating blood volume may be controlled and fluid overload prevented.

Electrolyte disturbances should be corrected before elective surgery. ${ }^{7,16,21}$ This is best achieved by haemodialysis. Since serum potassium fluctuates rapidly following dialysis, potassium levels should be determined immediately before operation. Values in excess of $5.5 \mathrm{mmol} / \mathrm{l}$ require therapy because persistent hyperkalae- mia may precipitate cardiac dysrhythmias during anaesthesia and surgery. ${ }^{14,16,21}$ In these patients, routine intravenous hydration and potassium supplementation for 12 hours before cardiac surgery is undesirable.

Although serum calcium is usually decreased during uraemia, it is seldom of clinical significance during anaesthesia unless alkalosis is induced. ${ }^{13}$ An infrequent complication of hypocalcaemia is the potentiation of muscle relaxants. Calcium is a useful inotropic agent and may be administered intravenously when needed.

Depression of platelet function, caused by the accumulation of phenolic acids in uraemia, may result in a prolonged bleeding time. ${ }^{16,21,22} \mathrm{Al}$ though this defect is correctable by haemodialysis, platelet count, bleeding time, prothrombin time and partial thromboplastin time should be determined before operation to evaluate platelet function and to detect other coagulopathies.

Careful monitoring during operation, including electrocardiogram, heart sounds, central venous pressure, temperature and intra-arterial pressure, appropriate for any patient with severe heart disease, is obligatory when renal failure co-exists. Some means of measuring left-sided cardiac filling pressures is essential for postoperative fluid management in the anuric patient. A flow-directed pulmonary artery catheter, or a catheter placed in the left atrium during surgery may be used for this purpose.

An indwelling arterial cannula provides continuous blood pressure monitoring and facilitates frequent sampling for electrolyte and blood gas analysis; the $\mathrm{pH}\left(\left[\mathrm{H}^{+}\right] \mathrm{a}\right), \mathrm{Pa}_{\mathrm{CO}_{2}}$ and $\mathrm{Pa}_{\mathrm{O}_{2}}$ should be maintained near normal. Respiratory alkalosis will shift the oxyhaemoglobin dissociation curve to the left further impairing oxygen delivery in the anaemic patient with chronic renal failure.

When selecting anaesthetics and adjuvant drugs for patients with both cardiac disease and chronic renal failure, the route of elimination must be considered in addition to their cardiac and peripheral vascular effects. Requirements for premedication vary widely; some patients may require little or none while others, especially those with coronary artery disease, may need substantial sedation to prevent an anginal attack. Since recovery from most premedicant drugs is by redistribution and hepatic metabolism, any sedative, hypnotic or narcotic agent, (in appropriate dosage), may be used in the patient with both cardiac and renal disease.

On the other hand, induction and maintenance of anaesthesia in the cardiac patient is complicated by the presence of renal failure. The use of large doses of morphine should be avoided since active metabolites may result in prolonged depression of the central nervous and cardiovascular systems. ${ }^{25,26}$ In addition, vasodilatation may require infusion of large volumes of fluid to maintain circulatory stability. ${ }^{24}$ Fentanyl, which causes less vasodilation, appear preferable to morphine. ${ }^{26}$ Ketamine has been used for aortic valve replacement in an anephric patient. "I Hypertension and tachycardia, resulting from its sympathomimetic properties, is undesirable in the patient with mitral stenosis or coronary artery disease. 
Slow induction and gradual loss of awareness with diazepam, followed by maintenance with an inhalation agent, has been satisfactory. The trachea is intubated when anaesthesia is sufficiently deep to minimize the pressor response to airway instrumentation. The potent inhalation agents, halothane and enflurane, facilitate appropriate regulation of anaesthetic depth. The possibility of fluoride nephrotoxicity induced by enflurane is of concern only in those patients who retain some functional renal tissue. The effects of inhalation anaesthetics on cardiac performance and metabolism are well known and will not be reviewed here.

Succinylcholine should be avoided when the patient is hyperkalaemic and surgery cannot be delayed, but otherwise may be used to facilitate tracheal intubation. ${ }^{16,17,21}$ Since plasma cholinesterase levels are not significantly decreased by haemodialysis using the newer dialysis membranes, ${ }^{21,28}$ prolonged paralysis is unlikely. Although metocurine has minimal cardiovascular effects and might be considered the ideal long acting muscle relaxant for use in cardiac patients, the fact that it is exclusively excreted by the kidneys ${ }^{34}$ makes it inappropriate for the patient with chronic renal failure. For the same reason gallamine should be avoided. Pancuronium and tubocurarine are excreted by altemate pathways and may be used in the presence of renal failure although their duration of action may be increased. ${ }^{16.19,21,30,31}$ The use of pancuronium for muscle relaxation during halothane anaesthesia produces a more stable blood pressure than does tubocurarine. ${ }^{16,32}$

Intravenous fluid therapy for the cardiac patient is necessarily altered by the co-existence of renal failure. With careful anaesthetic management, minimal fluid volumes are needed before cardiopulmonary bypass. Large fluid loads may reduce the haematocrit excessively. Although clear fluid priming of the pump-oxygenator has become routine for most cardiac surgery, the addition of blood to the priming solution may be necessary in the patient with chronic renal failure to prevent excessive haemodilution during bypass. After bypass, whole blood or packed cells are given as required to maintain blood volume and haematocrit. Crystalloid solutions must be administered cautiously following bypass, since any excess cannot be eliminated by diuresis. Potassium-containing solutions should be avoided unless potassium is required to correct a measured deficit. Serum potassium should be measured at least hourly during operation because wide fluctuations may occur during and after cardiopulmonary bypass. Regular postoperative serum electrolyte determinations can help to guide intravenous fluid therapy and to monitor changes in serum potassium.

Cardioplegic solutions, commonly containing $15-35 \mathrm{mmol} / 1$ of potassium, are now widely used for myocardial preservation during cardiac surgery. Unless an effort is made to discard the coronary sinus effluent during cardioplegia, the additional potassium will enter the circulation. Transient hyperkalaemia may occur while on bypass, but equilibration will result in an insignificant change in serum potassium unless unusually large amounts of cardioplegic solution are administered.

Haemodialysis is normally resumed the day after the operation. However it may be necessary to institute it earlier if correction of hypervolaemia or hyperkalaemia is indicated. ${ }^{14,16}$ Hyperkalaemia alone may be treated with ion exchange resins (Kayexelate ${ }^{\text {( }}$ ) or simultaneous administration of glucose and insulin. ${ }^{16}$ Calcium or sodium bicarbonate may be administered to treat acute, severe hyperkalaemia.

In conclusion the anaesthetic management of open-heart surgery is made more complex by the presence of chronic renal failure. Thorough knowledge of the pathophysiology involved is necessary to guide the anaesthetist in his choice of agents and techniques.

\section{REFERENCES}

1. Merrill, J.P. Cardiovascular problems in patients on long-term dialysis (Editorial). N. Engl. J. Med. 228: 1149 (1974).

2. Lindner, A. Charra, B., Sherrard, D.T. \& SCRIBNER, B.H. Accelerated atherosclerosis in prolonged maintenance hemodialysis. N. Engl. J. Med. 290: 697-701 (1974).

3. King, L.H., Bradley, K.P., Shires, D.L., DONOHUE, J.P. \& GLOVER, J.L. Bacterial endocarditis in chronic hemodialysis patients: A complication more common than previously suspected. Surgery 69: 554-556 (1971).

4. Menzoian, J.O., Davis, R.C., Idelson, B.A., MANNICK, J.A. \& BERGER, R.L. Coronary artery bypass surgery and renal transplantation: A case report. Ann. Surg. 179: 63-64 (1974).

5. Lamberti, J.J. JR., COhN, L.H. \& Collins, J.J. Cardiac surgery in patients undergoing renal dialysis or transplantation. Ann. Thorac. Surg. 19: 135-141 (1975).

6. WILCOX, B.R., AsaPH, J.W. \& Brown, D.R Aortic valve replacement in the anephric patient. Ann. Thorac. Surg. 20: 282-288 (1975).

7. Manhas, D.R. \& Merendino, K.A. The management of cardiac surgery in patients with 
chronic renal failure: A report of three cases. J Thorac. Cardiovasc. Surg. 63: 235-239 (1972).

8. Lansing, A.M., Lea, D.E. \& Bermin, L.E Cardiovascular surgery in end-stage renal failure JAMA. 204: 134-138 (1968).

9. Connors, J.P. \& SHaw, R.C. Considerations in the management of open-heart surgery in uremic patients. J. Thorac. Cardiovasc. Surg. 75: 400-404 (1978).

10. AldRetTe, J.A. \& PapPas, G. Anesthetic implications for simultaneous cardiorenal transplant: A Case Report. Anesth. Analg. 48: 928-932 (1969).

11. Posner, M.A., Reves, J.G. \& Lell, W.A. Aortic valve replacement in a hemodialysisdependent patient: Anesthetic consideration - A case report. Anesth. Analg. 54: 24-28 (1975).

12. ANSARI, Z. \& BALDWIN, D.S. Acute renal failure due to radio-contrast agents. Nephron 17: 28-40 (1976).

13. Erslev, A.J. \& Shapiro, S.S. Hematologic aspects of renal failure. In: Strauss MB, Welt LG, editors. Diseases of the Kidney. Boston: Little, Brown and Company. p. 272-292 (1979).

14. Hampers, C.L., Bailey, G.L., Hager, E.B., VANDAM, L.D. \& MERRILL, J.P. Major surgery in patients on maintenance hemodialysis. Am. $\mathrm{J}$. Surg. 115: 747-754 (1968).

15. KIM, K.E., ONESTI, G. \& SWartz, C.D. Hemodynamics of hypertension in uremia. Kidney Int. (Suppl.). 2: S155-S162 (1975).

16. ZAUDER, H.L. Anesthesia for patients who have terminal renal disease. Hershey SG, editor. In: ASA Refresher Courses. p. 163-173 (1976).

17. Fuller, T.C., Delmonico, F.L., Cosimi, A.B., Huggins, C.E., King, M. \& Russell, P.S. Impact of blood transfusion on renal transplantation. Ann. Surg. 187 (2): 211-218 (1978)

18. Polesky, H.F., McCullough, J.J., Yunis, E. HELGESON, M.A., ANDERSEN, R.C.. SIMMONS, R.L. \& Najarian, J.S. The effects of transfusion of frozen-thawed deglycerolized red cells on renal graft survival. Transplantation 24 449-452 (1977).

19. Briggs, J.D., Canavan, J.S.F., Dick, H.M. Hamiton, D.N.H., KYLE, K.F., MacPherSON, S.G., PATON, A.M. \& Tirterington, D.M. Influence of HLA matching and blood transfusion on renal allograft survival. Transplantation 25: 80-85 (1978).

20. OPELZ, G. \& Terasakl, P.I. Improvement of Kidney-Graft Survival with increased numbers of blood transfusions. N. Engl. J. Med. 229: 799-803 (I978).

21. Bastron, R,D. \& DeUtsch, S. Anesthesia and the Kidney. New York: Grune and Stratton (1976)

22. Stewart, J.H. \& Castaldi, P.A. Uremic Bleeding: A reversible platelet defect corrected by dialysis. Q. J. Med. 36: 409-423 (1967)

23. LichtMan, M.A., MURPHY, M.S., BYER, B.J. \& FREEMAN, R.B. Hemoglobin affinity for oxygen in chronic renal disease: The effect of hemodialysis. Blood 43: 417-424 (1974).

24. Stanley, T.H., Gray, N.H., Isern-Amaral, J.H. \& Patron, C. Comparison of blood requirements during morphine and halothane anesthesia for open-heart surgery. Anesthesiology 41: 34-38 (1974).

25. Don, H.F., Diepra, R. A. \& TA Ylor, P. Narcotic analgesics in aneuric patients. Anesthesiology 42: 745-747 (1975)

26. Mostert, J.W., Evers, J.L., HobiKa, G.H., MOORE, R.H. \& ABRUSE, J.L. Cardiorespiratory effects of anesthesia with morphine or fentanyl in chronic renal failure and cerebral toxicity after morphine. Br. J. Anaesth. 43: 1053-1059 (1971).

27. Miller, R.D., Way, W.L., Hamilton, W.K. \& LAYZER, R.B. Succinylcholine-induced hyperkalemia in patients with renal failure? Anesthesiology 36: 138-141 (1972).

28. DESMOND, J.W. \& GoRDON, R.A. The effect of hemodialysis on blood volume and plasma chol. inesterase levels. Can. Anaesth. Soc. J. 16: 292-301 (1969)

29. Miller, R.D., Stevens, V.C. \& Way, W.L. The effect of renal failure and hyperkalemia on the duration of pancuronium neuromuscular blockade. Anesth. Analg. 52: 661-666 (1973).

30. Miller, R.D., Matteo, R.S., Benet, L.Z. \& SoHN, Y.J. The pharmacokinetics of d-tubocurarine in man with and without renal failure. J. Pharmacol Exp. Ther. 202: 1-7 (1977).

31. MCLEOD, K., WATSON, M.J. \& RaWLinS, M.D Pharmacokinetics of pancuronium in patients with normal and impaired renal function. Br. J. Anaesth. 48: 341-345 (1976).

32. Stoelting, R.K. Influence of pancuronium or d-tubocurarine on circulatory responses during thiamylal-nitrous oxide-halothane anesthesia. Anesth. Analg. 55: 485-488 (1976).

33. Savarese, J.J., Ali, H.H. \& ANtonio, R.P. The clinical pharmacology of metocurine: $\mathrm{Di}$ methyltubocurarine revisited. Anesthesiology 47: 277-284 (1977).

34. DaI SANTO, G. Kinetics of distribution of radioactive-labeled muscle relaxants. Anesthesiology 25: 788-800 (1964).

\section{RESUMÉ}

Deux cas d'insuffisants rénaux chroniques opérés à cæeur ouvert sont présentés. Les risques accrus de l'insuffisance rénale chronique surajoutés à l'anesthésie pour la chirurgie cardiaque sont discutés et des recommandations sont faites sur le choix des agents et techniques. 